\title{
International Organisations and the Shared Construction of Policy 'Problems': problematisation and change in education governance in Europe $\mathrm{e}^{[1]}$
}

\author{
SOTIRIA GREK \\ Centre for Educational Sociology, \\ University of Edinburgh, United Kingdom
}

\begin{abstract}
Over recent years, research has shown the ways that national governments have seemingly ceded some of their autonomy in education policy development to international organisations (IOs) in the context of globalisation and one of its conduits, Europeanisation. This article develops the idea that IOs, and particularly the Organisation for Economic Co-operation and Development (OECD), have had significant policy influence within the context of education policy development in the European education space. The article focuses on an examination of the OECD's Programme for International Student Assessment (PISA) and the more recent Programme for the International Assessment of Adult Competencies (PIAAC) in order to discuss processes of problematisation and normalisation of the notions of 'skills' and 'competencies' by the two major European IOs, the OECD and the European Commission. It examines the ways both concepts have turned into a policy problem in need of soft governance through new data, standards and policy solutions. The article presents work in progress as part of the new project Transnational Policy Learning: a comparative study of OECD and EU education policy in constructing the skills and competencies agenda, funded by the Economic and Social Research Council. It is therefore a speculative article, setting out the research agenda and explaining the reasons why the construction of policy problems at the European education policy level needs to be further problematised itself by the research community.
\end{abstract}

\section{Introduction}

Since the middle of the last century, international organisations (IOs) have been increasingly playing an influential role as 'purveyors of ideas' and as leading participants in the struggle over education policy content (Jones, 2007, p. 94). Over recent years, research has shown the ways that national governments have seemingly ceded some of their autonomy in education policy development to IOs in the context of globalisation and one of its conduits, Europeanisation. This article develops the idea that, apart from the focus on national education systems and their policy connections to the international, IOs, and particularly the Organisation for Economic Co-operation and Development (OECD), have had real policy salience within the context of education policy development in wider policy spaces such as the European education space and its main advocate, the European Commission (EC) and its agencies. While it remains significant as a think tank and producer of significant international comparative data, the OECD has taken on an enhanced role as a policy actor in Europe as it seeks for its niche in relation to other supranational agencies (Henry et al, 2001). 
Power $(1999,2003 a, b, 2004)$ and Strathern $(2000,2004)$ suggest that a 'metrological mood' (Power, 2004, p. 766) has increasingly become the mechanism through which education systems are measured and made accountable, and has permeated the structure and public face of IOs themselves. In Europe, during the pre-Lisbon era and due to subsidiarity [2], education governance's main modus operandi was non-binding cooperation in creating a common identity, fabricated through cultural symbols and exchange (Shore, 2000). However, since 2000, the EC's education policy-making tools have entirely changed, with greater emphasis on indicators and benchmarking, which drive change and push the 'growth and jobs' agenda forward (Grek, 2008). These new policy tools work as governing devices that, through negotiation and co-option, together with cross-comparison and competition, draw national systems closer into European and global frameworks and practices. Ultimately, they contribute to increased levels of Europeanisation of education, 'reflecting the complexity of processes which include, first, transnational flows and networks of people, ideas and practices across European borders; second, direct effects of EU [European Union] policy; and, finally, the Europeanizing effect of international institutions and globalization' (Grek et al, 2009, p. 122). As this article will show, similarly, although for much longer, the OECD has been cultivating and promoting technical expertise in creating comparable data sets, where countries can potentially measure the success of their education systems against others and shift their policy orientations accordingly. In this new context, notions such as lifelong learning and the knowledge economy have turned education departments in both organisations into central governing hubs. Thus, the development of new policy technologies, combined with the new significance of education redefined as (lifelong) learning, have together greatly enhanced the OECD's and EC's governing capacity, not simply in their use of monitoring and measuring, but crucially in the construction of specific policy 'problems' for the nations and thus the promotion of particular attitudes and dispositions to learning.

Using them as examples, this article examines the OECD's Programme for International Student Assessment (PISA) and the current development of the more recent Programme for the International Assessment of Adult Competencies (PIAAC) in order to discuss processes of problematisation and normalisation of policy issues by the two IOs (the OECD and EC). It examines the construction of policy problems (Dale, 1986) that are in need of soft governance through new data, standards and new policy solutions (Lawn, 2003). The article focuses on the nature of the problem, its contours, characteristics and shifting qualities. It discusses the ways that policy problems can be transformed into public issues with all-pervasive and all-inclusive effects that might often break the boundaries of interpretation derived from traditional political science and its research orthodoxies. It suggests that in order to understand the 'problem', one has to move behind it, since the very process of its creation already carries the seeds of its solution.

In terms of methodology, the article develops on text and interview data analysis derived from the recently completed Centre for Educational Sociology (CES) project Fabricating Quality in European Education (2006-09), funded by the Economic and Social Research Council, as well as preliminary research, based on documentation analysis, for the CES ESRC-funded project Transnational Policy Learning: a comparative study of OECD and EU education policy in constructing the skills and competencies agenda (2010-12)[see note 1]. The article starts with a discussion of the OECD's role in education policy development. It moves on to briefly discuss PISA and PIAAC and their impact on European education policy making. Finally, it discusses the role of the OECD as an agent of Europeanisation through, first, its use of science (mainly numbers and statistical reasoning) as a political activity and, second, its politics 'as a particular species of production of learning' (Latour, 2002, cited in Autès, 2007, p. 101).

\section{The Organisation for Economic Co-operation and Development and Education Policy}

Founded in 1961, the OECD is an IO with policy influence within its member nations, but also with increasing impact on a broader global scale. While it is primarily concerned with economic policy, education has taken on increasing importance within its mandate, especially since it has been reframed as central to national economic competitiveness. Papadopoulos (1994), in his institutional history of the OECD, states that education always had an 'inferred role' in respect of 
its economic significance. As will be shown, this inferred role has become more explicit in the context of post- cold war globalisation and the emergent knowledge economy. The end of the cold war and the apparent triumph of global capitalism have placed pressures on the purposes of the OECD and changed its remit in some ways.

Historically, the OECD's interest in education has been clearly linked to its overall economic objectives. It was only in 2002 that Education became a separate and permanent Directorate within the OECD - until then it had less certain institutional status, gaining a mandate every five years from the Council of the Organisation. Although the economistic focus on knowledge and research was not always the way in which education was seen within the IO (Rizvi \& Lingard, 2006), the era of any social justice claims is long over; in fact, for some time now, the social efficiency agenda has usurped the equity one, as evidenced in the OECD's programmes of work and policy reports. This is evident in its support and promotion of a particular view of educational aims linked to the requirements of a global knowledge economy and ideas about educational governance derived from new public management, increasingly promoting corporatised and privatised administration of education, outcome measures and knowledge as commodity (Lingard \& Grek, 2007). Perhaps the greatest impact of the contemporary educational policy agenda of the OECD has been in relation to its indicators agenda, including PISA and, more recently, PIAAC, and their contribution to the construction of a global educational policy field constituted through numbers. This has been described as a new form of governance within member nations, namely 'governing by numbers' (Nóvoa \& Yariv-Mashal, 2003; Ozga \& Lingard, 2007).

Martens (2007, p. 42) has contributed substantially to this discussion, suggesting that the 'comparative turn' - 'a scientific approach to political decision making' - has been the main driver of OECD success. Through its long-standing development of education statistics, reports and studies, it has achieved a brand which most regard as indisputable. The OECD's policy recommendations are accepted as valid by politicians and scholars alike, 'without the author seeing any need beyond the label "OECD" to justify the authoritative character of the knowledge contained therein’ (Porter \& Webb, 2004).

Drawing on Martens's (2007) ideas, we can see that there is a taken-for-grantedness about education indicators, despite all the commentary asking for contextualisation in their interpretation (for example, Nóvoa \& Yariv-Mashal, 2003), and this is indicative of the way in which they have become an accepted part of the contemporary educational policy lexicon across the globe, within and well beyond the OECD, and of their growing significance to the work of the OECD itself since the 1980s. PISA now accounts for approximately 30\% of the Education Directorate's budget within the OECD and is funded directly by participating nations (Grek, 2009). One could suggest that the OECD's greatest impact has been in its role in establishing governance by comparison (Martens, 2007). Indeed, as Antonio Nóvoa (2002, p. 144) argued: 'comparing must not be seen as a method, but as a policy ... the expert discourse builds its proposals through "comparative" strategies that tend to impose "naturally" similar answers in the different national settings".

Therefore, in its role as a policy actor, the OECD has created a niche as a technically highly competent agency for the development of educational indicators and comparative educational performance measures. OECD-defined and OECD-collected data on education systems in Europe are then intersected with EU data, contributing to the creation of a governable space of comparison and commensurability - the European education space (Nóvoa \& Lawn, 2002). Taken together, these factors account for the increased significance of the education work of the OECD, its contribution to the emergent global education policy field, and its enhanced role as a policy actor. In the next two sections, I look in more detail at the organisation and content of PISA and PIAAC.

\section{The Programme for International Student Assessment (PISA)}

PISA is conducted in three-yearly cycles and examines the knowledge and skills of 15-year-olds in compulsory education. Although it began as a joint study of the OECD member countries, it has developed its scope to involve non-member countries as well. Indeed, since the year 2000, when the first PISA study was conducted, more and more countries have been taking part, with the latest PISA (2009) having assessed students in 66 countries all over the world, thus involving 36 nonmember participant nations. This shows the significance given to the test globally, since even 
countries which are not OECD members want to be seen to be taking part in the international comparison.

PISA has become the OECD's platform for policy construction, mediation and diffusion at a national, international and possibly global level (Grek, 2009). Decontextualisation, commensurability and policy orientation have been the key ingredients contributing to its success. While always testing reading, mathematical and scientific literacy, PISA's innovative dimension and part of its interest as a governing device - lies in the fact that, as noted above, it does not examine students' mastery of school curricula; rather, the focus is on an assessment of young people's ability to practically apply their skills in everyday-life situations. The focus on 'real-life' circumstances and on students' capacity to enter the labour market with core competencies, such as literacy and numeracy, has taken PISA's focus of interest away from less explicit educational aims that resist measurement (for example, democratic participation, artistic talents, understanding of politics, history, etc.) towards a more pragmatic view of education's worth: 'its relevance to lifelong learning' (Organisation for Economic Co-operation and Development, 2003).

This is significant, since lifelong learning is seen to expand and include compulsory education. This emphasis on skills and competencies is indicative of the concern to embed responsibility for continuous self-improvement and upskilling in the individual learner from a relatively early stage in his/her development. It connects the production of data to the growing self-governance of active subjects, and extends governance into a system of self-regulation (Rose, 1992; Ball, 1998). Finally, a key feature of PISA is 'its policy orientation, with design and reporting methods determined by the need of governments to draw policy lessons' (Organisation for Economic Co-operation and Development, 2003).

Hence, it is made clear that this is not simply a testing regime - it is constructed and operates under a clear and specific policy framework, which is to be adopted by the participant countries if they are to improve their future PISA assessments and thus improve their standing in attracting economic and human capital investment. Performance-based testing lies at the heart of the PISA project; it is focused on outputs, therefore always projected forward into students' lives and national futures. Hence, it ensures for itself its own 'lifelong' continuation. It is performed in cycles and therefore needs follow-ups, 'repeats', more rounds - moreover, as we will see in the next section, the recent development of PIAAC guarantees the OECD's lifelong monitoring of learners' trajectories. No matter the 'score', 'correcting' practices need to start immediately after the publication of the results. This is the effect of PISA (and other international comparative data). PISA does not simply produce 'truths'; it creates an incessant apparatus of self-control and improvement.

Apart from PISA's impact on national education systems in Europe, it also plays a rather indirect, less obvious but no less important role in the governance of the European education space overall (Grek, 2009). Interview data with policy actors at the EC show how PISA's explicit policy orientation often goes unchallenged and the focus is upon the data rather than the ideological basis on which they are collected (Grek, 2009). PISA is seen as an objective assessment of 'good' or 'bad' performance that currently lacks contextualisation and that more 'traditional' European methods, such as European networks and policy experts, can work on. The OECD's technical expertise, and PISA in particular, has become the impetus for a drive in the EC towards establishing its own political and technical capacity to produce better or more relevant education data.

\section{The Programme for the International Assessment of Adult Competencies (PIAAC)}

As already discussed, the notions of skills and competencies have been central to the OECD through its PISA work. A major study that prepared the ground for the development of PIAAC was the OECD's Definition and Selection of Competencies (DeSeCo) project (1997-2005), an effort to provide 'a sound conceptual framework to inform the identification of key competencies, to strengthen international assessments, and to help to define overarching goals for education systems and lifelong learning'.[3] In addition, the OECD has already conducted two international adult skills surveys: the International Adult Literacy Survey (IALS) (1994-96) and the Adult Literacy and Life Skills Survey (ALL) (2002-06). 
Post-PISA success, PIAAC is the new OECD multicycle programme of assessment. In contrast to PISA, it is not organised solely by the Education Directorate but by a collaboration of the latter with the OECD's Directorate for Employment, Labour and Social Affairs. Already under way, it will deliver its first test in 2011, aiming to help governments to go further in evaluating and designing education and training policies by providing comparative information on skills among their adult populations'.[4] Twenty-four OECD member countries will take part in the first cycle of the programme, in addition to three non-member countries (Estonia, Malta and Slovenia). The study has received high recognition and is being promoted at the very top level of the OECD as greatly ambitious. It is in line with the OECD's economistic view of education and knowledge:

Knowledge and skills are the most valuable assets to present and future generations, as governments seek to maintain global competitiveness, increase the flexibility and responsiveness of labour markets and deal with issues of population ageing. OECD’s breakthrough survey on adult competencies, PIAAC, will provide governments with a unique and effective tool to assess where they stand in terms of quantity and quality of the knowledge and skills of their workforce. Equally important, it will provide insights into how skills relate to the social and economic wellbeing of individuals and nations and also benchmark how effectively education and training systems meet emerging skill demands. (Angel Gurría, OECD Secretary General, cited in Organisation for Economic Co-operation and Development, 2008, p. 1)

Interestingly, PIAAC is also in line with European aspirations and targets:

Many countries adhere to national and multi-national statements of intent regarding the achievement of economic performance targets relative to international norms. An example is the declaration from the March 2000 meeting of the European Council in Lisbon ... Monitoring of progress in meeting such international targets necessarily requires international comparisons.

(Schleicher, 2008, p. 629)

The survey's results will be presented in 2013 and they will be based on interviews with 5000 adults (16-65 years old) in each participating country, in order to assess their literacy and numeracy skills and 'their ability to solve problems in technology-rich environments'. The test will also collect information in relation to how adults use their skills at work and in the community (Organisation for Economic Co-operation and Development, 2008, p. 2).

Unlike PISA, which is designed and analysed by the Australian Council for Educational Research (ACER), the design and implementation of PIAAC is the responsibility of an international consortium of research organisations in North America and Europe, led by the Educational Testing Service in the USA.[5] PIAAC's core features include: literacy in the information age; the use of key work skills through the Job Requirements Approach (JRA) questionnaire; and a background questionnaire which will measure skill formation and economic and social outcomes (Organisation for Economic Co-operation and Development, 2004). It is expected that the JRA, which has already been applied in the United Kingdom Skills Survey, will explain salary variations and employment opportunities not only based on longer learning trajectories, but also through 'influence skills', such as persuasion and presentation skills. The JRA pilot unfolded in five countries (Australia, France, Greece, South Korea and the USA), and its results were presented at an International Validation Seminar at an EC agency, the European Centre for the Development of Vocational Training (Cedefop), in February 2009. According to Mark Teese, a senior OECD economist at another joint JRA OECD-Cedefop workshop held in Paris in May 2008, the JRA 'will open up a new world for investigating the demand for a range of generic work skills and the implications for education and training policies'.[6]

According to their work programme [7], the EC's Centre for Research on Lifelong Learning (CRELL) has substantially contributed to the development of the PIAAC background questionnaire. In addition, a Coordination Group has been established by the EC DirectorateGeneral for Education and Culture for cooperation with the OECD in the area of adult skills and PIAAC in particular; most importantly, a total amount of 1.05 million euros was budgeted in the 2008 EU budget for the support of European countries in PIAAC. Therefore, we see that apart from the mainly German and American-based research consortium responsible for the study, the EC, through its agencies and, in particular, Cedefop and CRELL, has been closely engaged in the preparation of PIAAC. 
On the other hand, the centrality of skills and competencies in the policy work of the EC has emerged in tandem with labour market changes, the dominance of the service market industries in Europe and the USA, and the requirement by business that education systems prepare a flexible workforce (Brown et al, 2001; Lauder et al, 2008). In Europe, skills and competencies have been at the forefront of policy from quite early on in the EC's education work; since the 1970s, training and vocational education have been the primary focus of collaborative work bringing European education systems closer together (Pépin, 2006). This policy area is thus of particular interest, not just for its centrality in working towards 'becoming the most competitive and dynamic knowledgebased economy in the world' (European Council, 2000), but in providing a rich and suitable resource for the interrogation of EC policy work that enables the testing of the convergence and divergence of discourses and policy tools between the OECD and the EC. More recently, Cedefop, the European Centre for the Development of Vocational Training, has been working closely on the identification of skills needs in Europe through the Skillsnet project [8], as well as through CEDRA, the Cedefop Research Arena.[9] Numerous European Council resolutions and EC staff publications and working documents on the topic have also been published (European Council, 2007; European Commission, 2007a, b, 2008; Cedefop, 2008, 2009). These provide resources for examining and explaining the policy directions that both Cedefop and the EC have taken, as well as Eurostat, in building the skills and competencies agenda from the early 1990s to the present day.

Apart from the EC's own projects on framing the skills agenda, its recent involvement in the development of PIAAC with the OECD enables the investigation of the politics and practices around processes of problematisation at the transnational level and, more particularly, the collaboration between the EC and the OECD in education governance in Europe. Why and how has the OECD worked with the EC in developing the study? How have policy actors from the two organisations been working together on this project, and how do the two organisations see this new collaboration? What does this interaction suggest for the future instruments of education policy making in the European education space or, indeed, for education governance itself? The speculative 'agenda-setting' nature of this article does not have answers to these questions as yet. What it does, instead, is discuss and problematise transnational policy learning in the field of education - how it takes place, who is involved, why and what its impact is. The next section identifies points of convergence in the policy agenda of the two organisations and explores the reasons why their problem-framing processes appear increasingly shared and intertwined.

\section{International Organisations and the Shared Construction of Policy 'Problems'}

A considerable body of research has already focused on the education work of each of the two IOs (see, for example, Shore, 2000; Henry et al, 2001; Lawn \& Lingard, 2002; Lawn, 2003; Pépin, 2006; Martens, 2007; Ozga \& Lingard, 2007); however, this research does not examine the interaction between them. IOs are often seen as monolithic institutions, or actors with similar interests in a similar context, without attention to the complex set of realities that brings them together and apart over time. Thus, important questions about 'what mechanisms work, in what ways, for whom and under what circumstances' (Dale \& Robertson, 2007, p. 219) are neglected, as is a detailed investigation of the extent and the means through which IOs may or may not unite in the construction and pursuit of mutual 'problems'.

This article attempts to initiate a discussion about the growing alliance between two influential international actors operating within the European education space. As has been shown, due to the impact of PISA on national education systems and European education policy making on the whole, and the more recent, unfolding collaboration with the EC in the development of PIAAC, the OECD has to be identified as a strong agent of Europeanisation, in charge of developing a mounting consensus among nations and IOs about the new pertinent policy agendas in education governance in Europe today. The OECD has accomplished this through the comparative turn, a shift towards 'a scientific approach to political decision making' that builds on data collection and the ranking and rating of member countries (Martens, 2007, p. 42). This approach highlights not only the significance of the OECD as an education policy agent, but, crucially, the emergence of a social matrix of interrelated governing actors in Europe that classify and construct meaning, and articulate and diffuse new norms and principles. 
One could argue that the commonalities between the policy instruments and content of the two IOs might simply reflect the dominance of 'rational choice' principles, such as efficiency and equity. Nevertheless, as already discussed, through the shared construction of indicators and data sets, as well as the numerous common workshops and meetings, one could easily identify a number of specific instances of policy teaching and learning between them. If this is the case, could we then observe a stable relationship or are we witnessing variances in the direction and density of the movement of this 'magistracy of influence' (Lawn \& Lingard, 2002) in engendering shared processes of problematisation? What are the transformation capacities (Weiss, 1998) of the two IOs when they receive policy tools and ideas, and how do they adapt them to their own interests and practices? Is the learning process promoted or disrupted by expert players (Tsebelis, 2002; Boswell, 2009)? For example, organisations like the Council of Europe have long promoted the idea of a social Europe and thus resisted the current emphasis on linking education policy to 'growth and jobs'. Is its position peripheral or central in the matrix of policy actors involved in constructing the skills and competencies agenda? Finally, what happens when the EC acquires access to Australian, Canadian and American expertise, or when the OECD meets with EC experts? Have OECD politics and policies been changing through relations with external contractors and advisers, as well as the EC itself?

Through the examination of skills and competencies, this article has tried to demonstrate the mutual efforts by the two IOs not simply to frame new problems, but in fact to share new ideas about how IOs can 'do' education governance in Europe. There is necessity for further research into this joint venture in order to investigate in depth some of the questions outlined above as well as engender new ones. To the extent that the argument presented here could pinpoint towards some explanation of this transnational enterprise, our attention needs to be directed to two interlinked ideas - policy learning and knowledge politics.

First, the idea of policy learning (May, 1992; Haas \& Haas, 1995; Bennett, 1997; SteinerKhamsi, 2004; Raffe \& Spours, 2007) is central to the understanding of processes of problematisation and normalisation within education governance. It is not limited to the idea of instrumental learning, or learning about new policy tools or interventions; instead, it encompasses an idea of social policy learning which entails 'new or reaffirmed understanding of policy problems and objectives' (May, 1992, p. 334) - the social construction of policy priorities. It also takes account of 'political' learning, which involves processes that take place in advocacy coalitions, such as the one that this article has suggested between the OECD and EC. On the other hand, the idea of policy teaching (Bomberg, 2007) is also significant in that it assumes that the learning of specific policy instruments not only depends on 'learners' but also on those agents responsible for promoting and inducing that learning. Although it is important to look at who is learning, what is learned and to what effect, it is equally significant to focus on who is teaching, what is taught and to what effect (Bomberg, 2007). It is crucial to investigate the cascading strategies of 'teachers', as well as the take-up of ideas by 'model pupils' (Rinne, 2006).

Second, closely interlinked with the idea of policy learning is the centrality of knowledge in processes of problematisation between the two IOs. Through the examination of PISA and PIAAC, we witness an evolving and progressing consensus based on the co-construction of knowledge, and crucially statistical knowledge, in education. The processes of problematisation are thus rooted in knowledge and expertise and their ever expanding territories - but this is not to say that knowledge here becomes an uncontrollable force which has acquired a life of its own. On the contrary, it is a social construct heavily managed and steered through a series of expert meetings and exchanges and this is where policy learning becomes intimately entangled with knowledge politics. These European encounters are not limited within the boundaries of one organisation, or even two, as this article might have tried to show, and sometimes they are not even confined within European boundaries at all. They include a wide range of actors, with different interests and opportunities, which need to be traced every single time one attempts to examine the construction of a policy problem from scratch. Knowledge is the main engine powering the construction of policy problems (what this article initially described as moving 'behind' the problem in order to understand the reasons for its genesis), since numbers can be collated, monitored and interpreted by different states and actors, and even used as a basis for forecasting future needs (Grek, 2008). Knowledge is key here: education policy is heavily dependent on knowledge policy and politics. To a large -and constantly increasing - extent, the management of knowledge appears to determine 
the orientation of education policy. This is not a neutral, apolitical process; rather, it is heavily political and directed. This article argues that the analysis of knowledge policy is crucial in order to explain problematisation and change in education governance in the knowledge society (Grek \& Ozga, 2010).

Therefore, the relationship between the two IOs is a new knowledge relationship - the interest is not only in what they have been learning through this collaboration but also, crucially, in the terms on which they have been both involved in this knowledge exchange. During these processes, policy problems are never static because the knowledge that brings them about constantly increases. In addition, the creation and appropriation of such knowledge is always only temporary - new actors and experts always emerge and demand to control the knowledge game themselves. Technologies and technicians need to become part of the same problem. Consensus building appears to pre-date any processes of problematisation, and this is the area where the OECD has done expert work, since it managed to bring around the same table very divergent interests and actors. Knowledge is central in this success because it is the apparent neutrality and objectivity of scientific expertise that permits actors to get involved without risking their claimed authority. During the process and due to the magnitude of the exercise, statistics acquire a new significance; they turn into a spectacle with winners and losers. Thus, policy problems become public issues - the media have been playing a very significant role in this and the communication strategies of the IOs, and especially of the OECD, have ensured that they do so.

We need to be alert to the qualities of policy problems when they operate as such performance displays. One could perhaps speculate that, as it currently stands, the PISA phenomenon in Europe might not have managed to have perpetual endurance. Like a meteor, it hits the nation, creates some serious ripple effects, but is as quick to disappear and be forgotten. However, PISA data are necessary now as part of the PIAAC new data dream - both surveys together extend our knowledge backwards and forwards in any one person's life; within the context of lifelong learning, one needs the lifelong monitoring of education. Despite the EC's longstanding policy interest in vocational training, statistical knowledge about skills and competencies in Europe was non-existent before. The EC had to jump on the OECD's numbers bandwagon, since new indicators and standards - new problems - are going to be produced out of the knowledge acquired.

In conclusion, this article argues that the knowledge and policy relationship that has emerged between the OECD and the EC is neither superficial nor temporary; rather, it is becoming deeper and relates to wider questions about how one does education governance in Europe today. Policy problems are hard to isolate and examine as they constantly move and change. They have to adopt and adapt. This is what PISA has taught the OECD and the education policy and research worlds. Policy problems are multidimensional, as they have to fit every country's ranking position and its politics. They are temporal, as they always change and adjust to the wider societal and political sphere (for example, the centrality of skills as a policy priority has been strengthened due to the financial crisis). They are spatial, as they have different effects and reconfirm arcs of prosperity (Scandinavia) and arcs of poverty (the Mediterranean). Above all, problems are both moral (the equity discourse is always present in policy texts around these issues) and economistic (the knowledge economy is the major driver behind these shifts). Therefore, we observe that as they develop, policy problems appear to be constantly creating an all-inclusive and pervasive character for themselves. However, what is the special bond cementing all these different pieces together in such a well-orchestrated game? It seems that knowledge politics (Stehr, 2004), and more precisely the management of knowledge in education governance, in conjunction with policy learning, is increasingly becoming the most influential factor determining processes of problematisation and the setting of new education policy agendas in Europe.

\section{Notes}

[1] This article draws on research in progress on the project Governing by Numbers: data and education governance in Scotland and England (RES-00-23-1385; Principle Investigator Professor Ozga), funded by the Economic and Social Research Council (ESRC), which is part of the Eurocores Fabricating Quality in European Education project of the European Science Foundation; and on the ESRCfunded project Transnational Policy Learning: a comparative study of OECD and EU education 
policy in constructing the skills and competencies agenda (RES-000-22-3429; Principle Investigator Dr Grek).

[2] The term 'subsidiarity' was formally introduced with the Treaty of Maastricht in 1992, although it was not new in the field of education. It meant the exclusion of any harmonisation of the laws and regulations of the member states - education, like health and culture, would be retained as a competence for the member states alone (Pépin, 2006).

[3] http://www.deseco.admin.ch/

[4] http://www.oecd.org/document/57/0,3343,en_2649_37455_34474617_1_1_1_37455,00.html

[5] The other members of the consortium are: Westat in the USA; cApStAn in Belgium; the Research Centre for Education and the Labour Market (ROA) at the University of Maastricht in the Netherlands; and the GESIS-ZUMA Centre for Survey Research, the German Institute for International Education Research (DIPF), and the Data Processing Centre of the International Association for the Evaluation of Educational Achievement (IEA) in Germany.

[6] http: / / www.cedefop.europa.eu/etv/upload/etvnews/news/3501att1-1-05_progress_with_the_jra_pilot_mark_keese.pdf

[7] http:/ / crell.jrc.ec.europa.eu/WP/Workprogramme\%202006-07.doc

[8] http:/ / www.cedefop.europa.eu/EN/about-cedefop/networks/skillsnet/index.aspx

[9] http: / /www.trainingvillage.gr/etv/Projects_Networks/Cedra /

\section{References}

Autès, M. (2007) The Links between Knowledge and Politics, in B. Delvaux \& E. Mangez (Eds) Literature Reviews on Knowledge and Policy. Thematic Report. Knowledge and Policy in Education and Health Sectors. http: / / www.knowandpol.eu/index.php?id=98

Ball, S.J. (1998) Big Policies/Small World: an introduction to international perspectives on education policy, Comparative Education, 34(2) 119-130. http:/ / dx.doi.org/10.1080/03050069828225

Bennet, C. (1997) Understanding Ripple Effects: the cross-national adoption of policy instruments for bureaucratic accountability, Governance, 10(3), 213-233. http:/ / dx.doi.org/10.1111/0952-1895.401997040

Bomberg, E. (2007) Policy Learning in an Enlarged European Union: environmental NGOs and New Policy Instruments, Journal of European Public Policy, 14(2), 248-268. http: / / dx.doi.org/10.1080/13501760601122522

Boswell, C. (2009) The Political Uses of Expert Knowledge: immigration policy and social research. Cambridge: Cambridge University Press.

Brown, P., Green, A. \& Lauder, H. (2001) High Skills: globalisation, competitiveness and skill formation. Oxford: Oxford University Press.

Cedefop (2008) Future Skill Needs in Europe: medium-term forecast, synthesis report. Luxembourg: Office for Official Publications of the European Communities.

Cedefop (2009) Future Skills Supply in Europe: medium-term forecast, synthesis report. Luxembourg: Office for Official Publications of the European Communities.

Dale, R. (1986) Perspectives on Policy Making, in Module 1. Introducing Education Policy: principles and perspectives. Milton Keynes: Open University Press.

Dale, R. \& Robertson, S. (2007) New Arenas of Global Governance and International Organisations: reflections and directions, in K. Martens, A. Rusconi \& K. Lutz (Eds) Transformations of the State and Global Governance, 217-228. London: Routledge.

European Commission (2007a) Key Competences for Lifelong Learning: European reference framework. Luxembourg: Office for Official Publications of the European Communities.

European Commission (2007b) Towards More Knowledge-based Policy and Practice in Education and Training. Commission Staff Working Document, SEC(2007) 1098, Brussels. http: / / ec.europa.eu/dgs/education_culture/publ/pdf/educ2010/sec1098_en.pdf

European Commission (2008) New Skills for New Jobs: anticipating and matching labour market and skills needs. Commission Staff Working Document Accompanying the Communication from the Commission to the European Parliament, the Council, the European Social and Economic Committee and the Committee of the Regions, SEC(2008) 3058, Brussels, 16 December. http:/ / ec.europa.eu/education/lifelonglearning-policy/doc/sec3058_en.pdf 
European Council (2000) Presidency Conclusions. Lisbon European Council, 23 and 24 March 2000. http:/ / www.europarl.europa.eu/summits/lis1_en.htm

European Council (2007) Council Resolution of 15 November 2007 on the New Skills for New Jobs, Official Journal of the European Union, 4 December, C 290/01.

Grek, S. (2008) From Symbols to Numbers: the shifting technologies of education governance in Europe, European Education Research Journal, 7(2), 208-218. http: / / dx.doi.org/10.2304/ eerj.2008.7.2.208

Grek, S. (2009) Governing by Numbers: the PISA 'effect' in Europe, Journal of Education Policy, 24(1), 23-37. http: / / dx.doi.org/10.1080/02680930802412669

Grek, S., Lawn, M., Lingard, B. \& Varjo, J. (2009) North by Northwest: quality assurance and evaluation processes in European education, Journal of Education Policy, 24(2), 121-133. http: / / dx.doi.org/10.1080/02680930902733022

Grek, S. \& Ozga, J. (2010) Reinventing Public Education: the new role of knowledge in education policy making, Public Policy and Administration, 25(3), 271-288. http:/ / dx.doi.org/10.1177/0952076709356870

Haas, P.M. \& Haas, E.B. (1995) Learning to Learn: improving international governance, Global Governance, 1, 255-285.

Henry, M., Lingard, B., Rizvi, F. \& Taylor, S. (2001) The OECD, Globalization and Education Policy. Oxford: Pergamon Press.

Jones, P.W. (2007) Education and World Order, Comparative Education, 43(3), 325-337. http: / / dx.doi.org/10.1080/03050060701556273

Latour, B. (2002) La Fabrique du droit: une ethnographie du Conseil d’État. Paris: La Découverte.

Lauder, H., Brown, P. \& Ashton, D. (2008) Globalisation, Skill Formation and the Varieties of Capitalism Approach, New Political Economy, 13(1), 19-35. http: / / dx.doi.org/10.1080/13563460701859678

Lawn, M. (2003) The 'Usefulness' of Learning: the struggle over governance, meaning and the European education space, Discourse, 24(3), 325-336. http: / / dx.doi.org/10.1080/0159630032000172515

Lawn, M. \& Lingard, B. (2002) Constructing a European Policy Space in Educational Governance: the role of transnational policy actors, European Educational Research Journal, 1(2), 290-307. http: / / dx.doi.org/10.2304/ eerj.2002.1.2.6

Lingard, B. \& Grek, S. (2007) The OECD, Indicators and PISA: an exploration of events and theoretical perspectives. FabQ Working Paper 2. Edinburgh: Centre for Educational Sociology, University of Edinburgh. http:/ / www.ces.ed.ac.uk/ research/FabQ/publications.htm

Martens, K. (2007) How to Become an Influential Actor: the 'comparative turn' in OECD education policy, in K. Martens, A. Rusconi \& K. Lutz (Eds) Transformations of the State and Global Governance, 40-56. London: Routledge.

May, P.J. (1992) Policy Learning and Failure, Journal of Public Policy, 12(4), 331-354. http: / / dx.doi.org/10.1017/S0143814X00005602

Nóvoa, A. (2002) Ways of Thinking about Education in Europe, in A. Nóvoa \& M. Lawn (Eds) Fabricating Europe: the formation of an education space. Dordrecht: Kluwer.

Nóvoa, A. \& Lawn, M. (Eds) (2002) Fabricating Europe: the formation of an education space. Dordrecht: Kluwer.

Nóvoa, A. \& Yariv-Mashal, T. (2003) Comparative Research in Education: a mode of governance or a historical journey? Comparative Education, 39(4), 423-438.

http: / / dx.doi.org/10.1080/0305006032000162002

Organisation for Economic Co-operation and Development (2003) PISA - The OECD Programme for International Student Assessment. http: / / www.pisa.oecd.org/dataoecd/ 51/27/37474503.pdf

Organisation for Economic Co-operation and Development (2004) PIAAC Draft Strategy Paper: policy objectives, strategic options and cost implications. COM/DELSA/EDU (2004)9, 2 November. http: / / www.oecd.org/ dataoecd/3/3/34463133.pdf

Organisation for Economic Co-operation and Development (OECD) (2008) The OECD Programme for the International Assessment of Adult Competencies (PIAAC). Paris: OECD.

Ozga, J. \& Lingard, B. (2007) Globalisation, Education Policy and Politics, in B. Lingard \& J. Ozga (Eds) The RoutledgeFalmer Reader in Education Policy and Politics, 65-82. London: Routledge.

Papadopoulos, G. (1994) Education 1960-1990: the OECD perspective. Paris: Organisation for Economic Cooperation and Development.

Pépin, L. (2006) The History of European Cooperation in Education and Training: Europe in the making - an example. Luxembourg: Office for Official Publications of the European Communities. 
Porter, T. \& Webb, M. (2004) The Role of the OECD in the Orchestration of Global Knowledge Networks. Paper presented at International Studies Association, Montreal, 17-20 March.

Power, M. (1999) The Audit Society: rituals of verification. Oxford: Oxford University Press.

Power, M. (2003a) Auditing and the Production of Legitimacy, Accounting, Organizations and Society, 28(4), 379-394. http: / / dx.doi.org/10.1016/S0361-3682(01)00047-2

Power, M. (2003b) Evaluating the Audit Explosion, Law and Policy, 25(3), 185-202. http: / / dx.doi.org/10.1111/j.1467-9930.2003.00147.x

Power, M. (2004) Counting, Control and Calculation: reflections on measuring and management, Human Relations, 57(6), 765-783. http: / / dx.doi.org/10.1177/0018726704044955

Raffe, D. \& Spours, K. (Eds) (2007) Policy-making and Policy Learning in 14-19 Education. London: Institute of Education, University of London.

Rinne, R. (2006) Like a Model Pupil? Globalisation, Finnish Educational Policies and Pressure from Supranational Organizations, in J. Kallo \& R. Rinne (Eds) Supranational Regimes and National Education Policies: encountering challenge, 183-216. Turku: Finnish Educational Research Association.

Rizvi, F. \& Lingard, B. (2006) Globalisation and the Changing Nature of the OECD's Educational Work, in H. Lauder, P. Brown, J. Dillabough \& A.H. Halsey (Eds) Education, Globalisation and Social Change. Oxford: Oxford University Press.

Rose, N. (1992) Governing the Enterprising Self, in P. Heelas \& P. Morris (Eds) The Values of the Enterprise Culture. London: Routledge.

Schleicher, A. (2008) PIAAC: a new strategy for assessing adult competencies, International Review of Education, 54(5/6), 627-650. http:/ / dx.doi.org/10.1007/s11159-008-9105-0

Shore, C. (2000) Building Europe: the cultural politics of European integration. London: Routledge.

Stehr, N. (2004) Introduction: a world made of knowledge, in N. Stehr (Ed.) The Governance of Knowledge. Edison, NJ: Transaction.

Steiner-Khamsi, G. (Ed.) (2004) The Global Politics of Educational Borrowing and Lending. New York: Teachers College Press.

Strathern, M. (Ed.) (2000) Audit Cultures: anthropological studies in accountability, ethics and the academy. London: Routledge.

Strathern, M. (2004) Commons and Borderlands: working papers on interdisciplinarity, accountability and the flow of knowledge. Wantage: Sean Kingston.

Tsebelis, G. (2002) Veto Players: how political institutions work. Princeton: Princeton University Press \& Russell Sage Foundation.

Weiss, L. (1998) The Myth of the Powerless State. Ithaca: Cornell University Press.

SOTIRIA GREK is a Research Fellow in the Centre for Educational Sociology at the University of Edinburgh, United Kingdom. Her research interests include education governance, education and European integration, analysis of educational policy discourse and the political economy of education. Correspondence: Sotiria Grek, Centre for Educational Sociology, University of Edinburgh, St John's Land, Holyrood Road, Edinburgh EH8 8AQ, United Kingdom (sotiria.grek@ed.ac.uk). 